\title{
Ownership Structure And Managerial Behavior To Beat Market Expectation In Korea
}

\author{
Hyewon Paik, Chungnam National University, Korea \\ YunSung Koh, Hankuk University of Foreign Studies, Korea
}

\begin{abstract}
This paper examines whether firm's ownership structure in Korea changes managers' behavior to meet or beat market expectations. We examine whether managers manage earnings upward and/or guide analyst expectations downward to avoid negative earnings surprises. By using companies listed on the Korean Stock Exchange, we find that the inclusion of a higher proportion of foreign ownership significantly increases the probability to meet or beat market expectations. The finding suggests that the firms with higher foreign ownership try to satisfy their foreign investors who emphasize current profits by boosting the stock price. We also find that managers are less likely to avoid negative earnings surprises as large shareholders' ownership increases. The results imply that large shareholders play an internal monitoring role for managers' earnings and/or expectations management. In addition, firms with large shareholders' ownership rely less on income-increasing discretionary accruals. Our findings supports the convergence-of-interest hypothesis that as the controlling shareholder's ownership level increases, the interest of the controlling shareholder decreases managers' opportunistic behavior to manage earnings.
\end{abstract}

Keywords: Ownership Structure; Beat Market Expectation; Foreign Ownership; Large Shareholder Ownership

\section{INTRODUCTION}

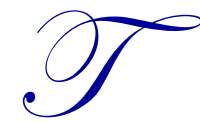

his paper investigates (a) whether the ownership structure in Korea is associated with managers' behavior to meet or beat market expectations; and (b) whether managers change to use earnings management and/or expectations management with the ownership structure. We use foreign ownership and large shareholder ownership in order to represent the ownership structure in Korea.

There are three earnings thresholds that managers seek to achieve (1) avoid losses, (2) avoid decreases in earnings and (3) avoid negative earnings surprises (Degeorge et al., 1999; Brown et al., 1987; Burgstahler \& Eames, 2006). Recent accounting studies suggest that meeting or beating analyst forecasts is an important benchmark for firms and further, firms are likely to manipulate earnings or guide market expectation downward to achieve such goal (Matsumoto, 2002; Brown \& Caylor, 2005). ${ }^{1}$ Growth stock strategists state that management attempts to be conservative in its earnings guidance as a result of how severely stocks are punished when earnings disappoint (Ip, 1997). The major reasons managers seek to meet or beat market expectations are to build credibility with capital markets and to maintain their firms' stock prices (Graham et al., 2005).

We examine the impact of ownership structure on managerial behavior to avoid negative earnings surprises in Korea. We expect the firms with higher foreign ownership are more likely to meet or beat market expectations, trying to satisfy their foreign investors who emphasize current profits by boosting the stock price. On the other hand, we expect the firms with large shareholders are less likely to meet or beat market expectations since the firms tend to be less short-term oriented and less sensitive to stock prices because the relationships between managers, who are mostly controlling shareholders and stakeholders, are maintained for a long time (Kaplan, 1994). Share ownership in

\footnotetext{
${ }^{1}$ Similar to Koh et al. (2008), we use the terms downward forecast guidance and expectations management, synonymously.
} 
Korea provides an interesting setting to examine monitoring efforts by documenting managers' opportunistic behavior. The ownership structure of most Korean firms is characterized by controlling shareholders who exercise nearly complete control over managers. If large shareholder ownership better aligns managers' interests with those of shareholders, we expect earning management decreases while expectations management increases.

Previous studies have not examined the Korean setting where unique ownership structures are observed regarding managers' behavior to meet or beat analysts' earnings forecasts. Different political and social environments are expected to have different incentives in order to meet or beat market expectations; the use of earnings management and/or expectations management will vary among countries, depending on ownership structures. Our findings showing that decreased earnings management as foreign ownership increases support that foreign ownership plays an important outside monitoring role in Korea. We expect managers alternately choose expectations management, however, we cannot find any significant result for expectations management as foreign ownership increases. Our study contributes to the debate on the effectiveness of internal monitoring mechanisms, supporting the convergence-of-interest hypothesis that as the controlling shareholder's ownership level increases, the interest of the controlling shareholder decreases managers' opportunistic behavior to manage earnings.

\section{RESEARCH QUESTION AND HYPOTHESES DEVELOPMENT}

\subsection{Meeting or Beating Market Expectations}

Recent studies find evidence consistent with managers taking action in order to avoid negative earnings surprises (Payne \& Robb, 2000; Brown, 2001; Burgstahler \& Eames, 2006; Matsumoto, 2002). Skinner and Sloan (2002) report that the stock market reaction to negative earnings surprises tends to be large and asymmetric, particularly for growth stocks, suggesting a high cost to missing analysts' expectations. Managers' behavior to avoid negative earnings surprises is also explained by the prospect theory. ${ }^{2}$ The prospect theory emphasizes that people tend to make a decision focused on loss-aversion rather than risk-aversion because losses hurt more than gains feel good.

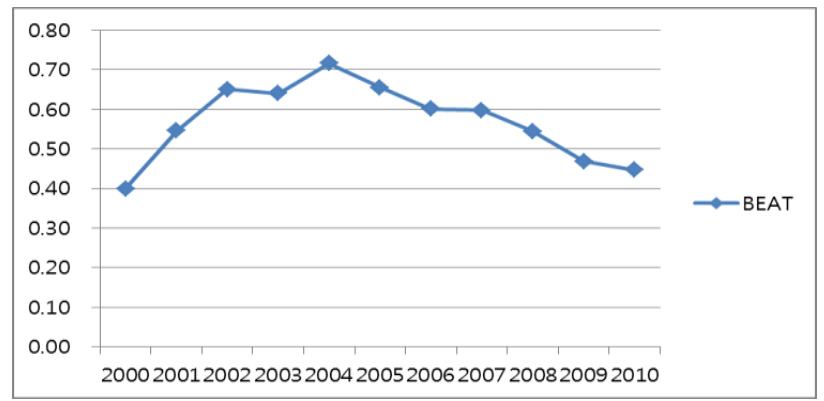

Figure 1: Trend over Time in the Probability of Meeting or Beating Analysts' Expectations in Korea

By utilizing Korean firms with analyst forecasts available in the $\mathrm{I} / \mathrm{B} / \mathrm{E} / \mathrm{S} /$ detail tape, we compute the percentage of firm-years, where the actual reported earnings per share meet or beat the consensus forecast one month prior to the earnings announcement for each year from 2000 to 2010. Similar to U.S. firms reported in Brown (2001), Richardson et al. (1999), and Matsumoto (2002), the percentage of years in which earnings meet or exceed analysts' expectations increased from 2000 to 2004. However, Figure 1 demonstrates that the percentage has more or less decreased after 2004. Even though the percentage of meeting or beating analysts' expectations has decreased recently, that from 2001 to 2008 is almost above 50 percent firm-years.

Generally, Korean investors' propensity to rely on analysts' earnings forecast when they make an investment decision is lower than that of U.S. investors. Moreover, analysts in Korea tend to report optimistic earnings forecasts, which make the percentage of meeting or beating market expectations lower than other countries.

\footnotetext{
${ }^{2}$ According to the prospect theory, investors evaluate firms' performance based on a certain reference point, which are the analysts' e arnings forecast in the stock markets. If the reported earnings exceed the reference point, the utility of investors increases. On the oth er hand, if the reported earnings are lower than the reference point, the utility decreases.
} 
However, prior studies find that certain firm characteristics are associated with greater incentives to meet or beat market expectations. By using Korean companies, Park and Jeon (2010) discover that firms, whose earnings are below analysts' estimates at the end of September, tend to manage their fourth quarter earnings in order to meet or beat analysts' forecasts at the earnings announcements.

\subsection{Ownership Structure}

\subsubsection{Foreign Ownership}

The 1997 financial crisis has created a drastic change in corporate governance within Korea. Moreover, after the 1997 crisis, foreign investors and institutional investors have increased steadily. Ahn et al. (2005) find that analyst coverage is significantly larger, and the analysts' earnings forecast error is significantly lower for firms with higher foreign ownership. They report that foreign investors in Korea do play a role as an effective external monitoring system in lessening information asymmetry. Shin et al. (2004) also find that there is a significant positive relation between foreign ownership and firm value. Shin and Chang (2005) find that the CEO turnover sensitivity with regards to performance increases with foreign ownership, indicating that the effectiveness of monitoring CEOs by foreign investors has improved after the economic shock in 1997-1998. On the other hand, Park et al. (2009) find that the magnitude of earnings management is positively associated with foreign investors' ownership. Moreover, foreign investors pay more attention to the firms' stock prices because they want a near-term portfolio performance. To the extent that foreign investors overemphasize near-term profits, managers with higher foreign ownership likely perceive greater costs to negative earnings surprises. Therefore, we hypothesize that firms with higher foreign ownership are more likely to meet or beat market expectations.

H1a: Firms with higher foreign ownership are more likely to meet or beat market expectations.

\subsubsection{Large Shareholder Ownership}

The ownership of listed companies in Korea is typically concentrated among large shareholders. When ownership is concentrated to a level at which an owner obtains effective control of the firm, the nature of agency conflicts is caused between the controlling owners and minority shareholders. According to the entrenchment effect, the controlling shareholders benefit from self-dealing transactions in which profits are transferred to the other companies they control (Fan \& Wong, 2002; La Porta et al., 1999). Outside investors may not trust the firm's reported earnings because the controlling owner may manipulate earnings for outright expropriation. As a result, the loss of credibility in the earnings report lowers the stock price informativeness of the earnings. According to Teoh and Wong (1993), market perception regarding the quality of accounting earnings positively affects stock price informativeness of earnings. Park (2003) finds that there is a positive relation between large shareholder ownership and discretionary accruals by using Korean firms.

On the other hand, the alignment effect implies that high ownership concentration can serve as a credible commitment as to which the controlling owner is willing to build a reputation for not expropriating minority shareholders (Gomes, 2000; Shleifer \& Vishny, 1986). Fan and Wong (2002) report that minority shareholders know that if the controlling owner unexpectedly extracts high levels of private benefits when he/she still holds a substantial amount of shares, they will discount the stock price accordingly and thus reduce the majority owner's share. Once the alignment effects are applied in Korea, as the controlling shareholder's ownership level increases, the interest of the controlling shareholder decreases managers' opportunistic behavior to manage earnings. Accordingly, as for firms with larger shareholder ownership, managers focus on long-term performance rather than boost current short-term profits. Therefore, we hypothesize that firms with larger shareholder ownership are less likely to meet or beat market expectations.

H1b: Firms with larger shareholder ownership are less likely to meet or beat market expectations.

\subsection{Method to Meet or Beat Market Expectations}

Prior studies examine two managerial responses in order to meet or beat analyst forecasts: accrual-based earnings management and earnings forecast guidance (Fields et al., 2001; Healy \& Palepu, 2001; Burgstahler \& 
Eames, 2006). Managing earnings is difficult because auditors and the board of directors scrutinize questionable accounting practices. In addition, because accruals reverse in subsequent periods, managers are unlikely to be able to use abnormal accruals in order to continually increase earnings above expectations every period (Matsumoto, 2002). The passage of the SOX, following the Enron accounting scandal, increased scrutiny on managers' opportunistic behavior to manage earnings. Due to the difficulty in managing earnings in the post-SOX period, managers now decrease the use of income-increasing discretionary accruals and increase the use of downward expectations management (Koh et al., 2008). While public policies regulating formal disclosures exist, public policies regulating informal disclosures are non-existent. Accordingly, in order to communicate with investors or analysts, managers favor informal channels, such as press releases, promotional material, speeches, or private conversations (Brown, 2001).

Ahn et al. (2005) show that Korean firms with higher foreign ownership have larger analyst coverage, but lower forecast error and discretionary accruals, indicating that foreign investors do play a role as an effective external monitoring system in lessening information asymmetry. Lee and Sohn (2005) report that by using Korean firms, foreign and institutional equity ownership significantly increases the level of disclosure. Therefore, we expect that firms who meet or beat market expectations rely less on earnings management and more on expectations management with higher foreign ownership. On the other hand, we expect that firms with larger shareholder ownership decreases both earnings management and expectations management once firms do not have strong incentives to avoid negative earnings surprises.

H2a: Firms that meet or beat market expectations are more likely to use upward earnings management.

H2b: The positive relation between firms who meet or beat market expectations and upward earnings management is weakened with higher foreign ownership.

H2c: The positive relation between firms who meet or beat market expectations and upward earnings management is weakened with larger shareholder ownership.

H3a: Firms that meet or beat market expectations are more likely to use downward expectations management.

H3b: The positive relation between firms who meet or beat market expectations and downward expectations management is strengthened with higher foreign ownership.

H3c: The positive relation between firms who meet or beat market expectations and downward expectations management is weakened with larger shareholder ownership.

\section{RESEARCH DESIGN AND DATA COLLECTION}

\subsection{Estimation Model of Earnings Management}

In order to measure earnings management through managers' accounting discretion, we use the performance matched model. It is a remodified version of the modified Jones model by Kothari et al. (2005). They argue that discretionary accruals can be affected by firm performance and also suggest including the ROA (return on assets) variable in the modified Jones model. The estimation model is shown below in Equation (1).

$$
\frac{T A_{t}}{A_{t-1}}=\beta_{0}+\beta_{1} \frac{1}{A_{t-1}}+\beta_{2} \frac{\Delta S_{t}-\Delta A R_{t}}{A_{t-1}}+\beta_{3} \frac{P P E_{t}}{A_{t-1}}+\beta_{4} R O A_{t}+\varepsilon_{t}
$$

where: $T A_{t}=$ Net income - cash flow from operations;

$S_{t}=$ Sales revenue;

$A R_{t}=$ Accounts receivables;

$P P E_{t}=$ Plant, property, and equipment;

$R O A_{t}=$ Net income / total assets;

$A_{t}=$ Total assets.

We use a cross-sectional model of discretionary accruals, where in each country for each year, we estimate the model for every industry classified by its KSIC (Korean Standard Industrial Classification) code. The sample includes only firms with ten or more firm-years of data in the same year-industry in order to ensure sufficient data 
for parameter estimations. The residual from the estimation model regarding Equation (1) is used to estimate the discretionary accruals. We classify firm-years with positive discretionary accruals $(P O S D A=1)$ as having upward earnings management, and those with negative discretionary accruals $(P O S D A=0)$ as having downward earnings management.

\subsection{Estimation Model of Expectations Management}

Similar to Matsumoto (2002) and Brown and Higgins (2005), we measure expectations management conditional on meeting or beating analysts' earnings forecasts. Specifically, expectations management is the unexpected portion of the earnings forecast $(U E F)$, measured by the difference between the consensus analyst forecast $(A F)$ and the expected analyst earnings forecast $(\mathrm{E}[A F])$ for the period:

$$
\begin{aligned}
& U E F_{t}=A F_{t}-E\left[A F_{t}\right] \\
& E\left[A F_{t}\right]=E P S_{t-1}+E\left[D R I F T_{t}\right] \\
& E\left[\text { DRIFT }_{t}\right]=\beta_{0}+\beta_{1} \frac{\left(E P S_{t-1}-E P S_{t-2}\right)}{P R I C E_{t-2}} \times P R I C E_{t-1}
\end{aligned}
$$

where: $A F_{t}=$ Mean of analyst earnings forecasts in one month prior to the earnings announcement;

$E\left[A F_{t}\right]=$ Expected analyst earnings forecasts calculated from Equation (3);

$E\left[D R I F T_{t}\right]=$ Expected drift estimated from Equation (4);

$E P S_{t}=$ Earnings per share;

PRICE $_{t}=$ Closing stock price.

The expected analyst forecast $(E[A F])$ in Equation (2) is modeled using a random walk model (EPS from the previous period) with drift (E[DRIFT]). Expected drift in Equation (3) is estimated based on prior earnings changes, where drift is the earnings change from the previous year. In Equation (4), we use the values of $\beta_{0}$ and $\beta_{1}$ only when they can be estimated using at least ten firms in the same year-industry. ${ }^{3}$ Comparable to Brown and Higgins (2005), we exclude the portion of the expected forecast reflected in the cumulative daily excess returns after the previous announcement.

If managers attempt to keep expectations low in order to avoid negative earnings surprises, then the actual consensus forecast will be less than the estimated forecasts; in Equation (2), UEF will be less than 0. More specifically, the negative value of $U E F$ implies that managers tend to guide forecasts downward. We classify firmyears with negative $U E F(D O W N=1)$ as having downward expectations management, and those with positive $U E F(D O W N=0)$ as having upward expectations management.

\subsection{Tests of Incentives to Beat Market Expectations}

To assess whether the ownership structure is associated with incentives to avoid negative earnings surprises, we employ the following regression:

$$
B_{E A T_{t}}=\alpha+\beta_{1} \text { FOR }_{t}+\beta_{2} \text { LARGE }_{t}+\beta_{3} \text { POSUE }_{t}+\beta_{4} \text { LOSS }_{t-1}+\beta_{5} \operatorname{SIZE}_{t}+\beta_{6} \text { GROWTH }_{t}+\sum_{n=7}^{15} \beta_{n} Y R+\varepsilon
$$

In Model (5), BEAT is a dummy variable that is set to one if the firm's actual earnings per share exceed the mean value of analysts' earnings forecasts in one month prior to the earnings announcement. In the distribution of analyst forecast errors, Burgstahler and Eames (2006) find a larger-than-expected proportion of zero and small

\footnotetext{
${ }^{3}$ Furthermore, our model and restriction to ten or more firms is similar to Matsumoto (2002) and Brown and Higgins (2005). 
positive forecast errors. In addition, not only the academic literature (Bartov et al., 2002; Brown \& Caylor, 2005) but also the financial press (Morgensen, 2004) discusses that managers try to exactly meet or narrowly beat analyst forecasts around the earnings announcement.

We focus on firm characteristics representing corporate ownerships, such as foreign ownerships $(F O R)$ and large shareholder ownerships ( $L A R G E)$. We expect a positive sign of $\beta_{1}(F O R)$ in that firms with higher foreign ownership are more likely to meet or beat analysts' earnings forecasts compared to other firms. Because foreign investors emphasize near-term profits to maximize stock prices, managers with higher foreign ownership are more likely concerned that the negative earnings surprises will lead to significantly lower stock prices. On the other hand, we expect the coefficient on $L A R G E$ to be negative, representing that firms with larger shareholder ownership are less likely to meet or beat expectations. Large shareholders tend to control managerial decisions and are not sensitive to current profits.

POSUE is a dummy variable that indicates firm-years with a positive seasonal change in net income. This variable controls for the relation between the change in earnings and the forecast error (Matsumoto, 2002). LOSS is a dummy variable set to one if the firm reports a net loss in the last year. We expect a negative relation between LOSS and its tendency to avoid negative earnings surprises since meeting or beating analysts' expectations is less important for firms that incur losses (Degeorge et al., 1999). SIZE is the logarithm of an equity's market value to control for firm size. Prior research shows that larger firms have less optimistic biases in analysts' forecasts (Brous \& Kini, 1993; Brown, 1997; Das et al., 1998). Once the less optimistic biases make it easier to meet or beat analysts' expectations, we expect a positive sign for SIZE. GROWTH represents the changes in total assets. Collins and Kothari (1989) demonstrate that market reaction to earnings announcements is greater for firms with high-growth opportunities. Therefore, we expect a positive sign of GROWTH in that managers of high-growth firms are likely to have greater incentives to avoid negative earnings surprises.

\subsection{Tests of Methods to Beat Market Expectations}

\subsubsection{Earnings Management}

We examine whether firms who try to meet or beat analyst estimates use upward earnings management and whether ownership structure affects the relationship between beating firms and earnings management. We employ the following regression:

$$
\operatorname{POSDA}_{t}=\alpha+\beta_{1} B E A T_{t}+\beta_{2} B E A T_{t} \times F O R_{t}\left(L A R G E_{t}\right)+\beta_{3} F O R_{t}+\beta_{4} L A R G E_{t}+\beta_{5} S I Z E_{t}+\beta_{6} G R O W T H_{t}+\sum_{n=7}^{15} \beta_{n} Y R+\varepsilon
$$

In Model (6), POSDA is set to one if the discretionary accrual estimated from Equation (1) is positive. We expect a positive sign for $\beta_{1}$ because firms who meet or beat analyst estimates are more likely to use incomeincreasing accruals compared to other firms. We examine whether the positive relationship between $B E A T$ and POSDA changes according to firms' ownerships, such as foreign ownership and large shareholders' ownership. We expect the sign of $\beta_{2}(B E A T \times F O R)$ to be negative, demonstrating that foreign ownership improves the effectiveness of monitoring managers. As for the coefficient on $B E A T \times L A R G E$, we expect it to be negative, representing a decline in the use of income-increasing accruals to meet or beat expectations regarding firms with large shareholder ownership.

\subsubsection{Expectations Management}

To assess whether the association between beating firms and the propensity for using downward forecast guidance changes according to corporate ownerships in Korea, we employ the following regression:

$D O W N_{t}=\alpha+\beta_{1} B_{E A T_{t}}+\beta_{2} \operatorname{BEAT}_{t} \times F O R_{t}\left(\operatorname{LARGE}_{t}\right)+\beta_{3}$ FOR $_{t}+\beta_{4} L A R G E_{t}+\beta_{5} \operatorname{SIZE}_{t}+\beta_{6} R O A+\beta_{7} G R O W T H_{t}+\beta_{8} N_{t}+\sum_{n=9}^{17} \beta_{n} Y R+\varepsilon$ 
In Model (7), $D O W N$ is set to one if $U E F$ is negative. $U E F$ refers to the unexpected forecasts provided by subtracting the expected forecast from the consensus of analyst forecasts for the year, as shown in Equation (2). If managers attempt to keep expectations low in order to avoid negative earnings surprises, $U E F$ will have a negative value because the actual consensus forecast is less than the estimated forecasts. In other words, a negative value implies that managers tend to guide forecasts downward. $R O A$ is ratio of net income t $_{\mathrm{t}}$ over total asset and $N$ indicates the number of individual analysts who issue earnings forecast for each firm.

We expect a positive sign for $\beta_{1}(B E A T)$ because firms that meet or beat analyst estimates are more likely to use expectations management compared to other firms. The positive sign of $\beta_{2}(B E A T \times F O R)$ shows that managers rely more on downward forecast guidance rather than income-increasing accruals. We also expect the coefficient for $B E A T \times L A R G E$ to be negative, representing a decline in the use of downward forecast guidance in order to meet or beat expectations regarding firms with larger ownership.

\subsection{Data}

The observations are selected from companies listed on the KSE (Korean Stock Exchange) as of December 31, 2010 that satisfy the following criteria: (1) companies (except financial companies) with their accounts closing in December; (2) companies with financial statements and analyst forecasts available in the Fn guide data base and the I/B/E/S detail tape, respectively. We use eleven years of data (2000 to 2010) that satisfy the above conditions. The value of analyst forecast accuracy exceeding $200 \%$ is eliminated. We divide our sample into thirteen groups according to the KSIC (Korean Standard Industrial Classification) code; additionally, observations that are in a yearindustry group with less than 10 samples are deleted in order to reduce bias in the estimating process. Furthermore, to minimize the effect of outliers, the top and bottom $1 \%$ of independent and dependent variables are winsorized. A total of 1,255 firm-year observations are used for the analysis.

\section{EMPIRICAL RESULTS}

\subsection{Univariate Tests}

Table 1 presents the descriptive statistics of the variables used in the analysis. The mean value of $B E A T$ is 0.587, suggesting that approximately 58.7 percent of firm-years meet or beat analyst forecasts during the sample periods. As for the methods to beat analysts' earnings forecasts, the mean value of POSDA is 0.520 and the mean $D O W N$ is 0.460 . The mean (median) regarding FOR is almost 23 percent (21 percent) percent, whereas the mean (median) for $L A R G E$ is 36.48 percent (35.29 percent). Our sample shows a relative high mean (median) regarding FOR because the I/B/E/S detail tapes from which we obtain the analyst forecast and actual earnings data have mostly covered large firms in Korea.

Table 1: Descriptive Statistics

\begin{tabular}{|c|c|c|c|c|c|c|}
\hline \multicolumn{2}{|c|}{ Variables } & Mean & STD & Min & Median & Max \\
\hline Beat analysts' forecasts & BEAT & 0.587 & 0.493 & 0.000 & 1.000 & 1.000 \\
\hline \multirow{2}{*}{$\begin{array}{l}\text { Methods to beat analysts' } \\
\text { forecasts }\end{array}$} & $P O S D A$ & 0.520 & 0.500 & 0.000 & 1.000 & 1.000 \\
\hline & DOWN & 0.460 & 0.499 & 0.000 & 0.000 & 1.000 \\
\hline \multirow{2}{*}{ Ownership } & FOR(\%) & 23.276 & 16.982 & 0.000 & 20.687 & 65.181 \\
\hline & $\operatorname{LARGE}(\%)$ & 36.480 & 15.972 & 5.810 & 35.290 & 86.620 \\
\hline \multirow{6}{*}{ Control variables } & POSUE & 0.635 & 0.482 & 0.000 & 1.000 & 1.000 \\
\hline & $L O S S_{t-1}$ & 0.036 & 0.187 & 0.000 & 0.000 & 1.000 \\
\hline & SIZE & 27.566 & 1.634 & 22.851 & 27.621 & 30.391 \\
\hline & GROWTH & 0.120 & 0.177 & -0.462 & 0.095 & 1.155 \\
\hline & $R O A$ & 0.080 & 0.059 & -0.177 & 0.070 & 0.278 \\
\hline & $N$ & 5.026 & 5.097 & 1.000 & 3.000 & 41.000 \\
\hline
\end{tabular}

$B E A T=1$ if actual $\mathrm{EPS}_{\mathrm{t}} \geq$ mean of analyst EPS forecast in 1 month before earnings announcement, otherwise 0; POSDA=1 if DA $\geq 0$, otherwise 0 (DA is residual value of performance matched model); $D O W N=1$ if $\mathrm{UEF}<0$, otherwise $0(\mathrm{UEF}=$ mean of analyst EPS forecast-expected analyst EPS forecast defined as equation (3)); FOR=foreign ownership; $L A R G E=$ large shareholders' ownership; POSUE=1 if net income $\geq$ net income $\mathrm{t}_{\mathrm{t}-1}$, otherwise $0 ; \operatorname{LOSS}_{t-1}=1$ if net income $\mathrm{t}_{-1}<0$, otherwise 0 ; SIZE=log of market value of equity; GROWTH=chages of total asset; ROA=ratio of net income $_{\mathrm{t}}$ over total asset; $N=$ number of individual analysts who issue earnings forecast for each firm. 
In Table 2, we compare the difference between BEAT and NO BEAT firm-years. There is a significant difference ( $\mathrm{p}<0.001)$ between the mean value of POSDA between firms who meet or beat analyst estimates, 0.579 and that of firms who miss analyst estimates, 0.433 . The mean value of $D O W N$ for firms who meet or beat market expectations, 0.470 , is relatively higher than $D O W N$ for firms who do not beat market expectations, 0.446 . Thus, we find support for the conjecture that firms who meet or beat analysts' earnings forecasts use both upward earnings management and downward expectations management.

As for the foreign ownership variable, the mean (median) regarding FOR for firms who meet or beat market expectations, 24.49 percent (21.61 percent), is relatively higher than FOR for firms who do not beat market expectations, 21.13 percent (18.23 percent). On the other hand, the mean (median) of LARGE for BEAT firms, 35.48 percent (35.20 percent), is relatively lower than LARGE for NO BEAT firms, 37.83 percent (35.69 percent). Therefore, we can conjecture that firms with higher foreign ownership are more likely to meet or beat market expectations while firms with greater large shareholder ownership are less likely to meet or beat analyst estimates.

Table 2: Beating Analysts' Earnings Forecast

\begin{tabular}{|c|c|c|c|c|c|c|}
\hline \multirow{2}{*}{ Variable } & \multicolumn{2}{|c|}{$\operatorname{BEAT}(\mathbf{N}=737)$} & \multicolumn{2}{|c|}{ NO BEAT $(\mathrm{N}=518)$} & \multirow{2}{*}{$\begin{array}{c}\text { Mean diff. } \\
\text { t-value }\end{array}$} & \multirow{2}{*}{$\begin{array}{c}\text { Median diff. } \\
\text { z-value }\end{array}$} \\
\hline & Mean & Median & Mean & Median & & \\
\hline POSDA & 0.579 & 1.000 & 0.433 & 0.000 & $4.29 * * *$ & $4.25 * * *$ \\
\hline$D O W N$ & 0.470 & 0.000 & 0.446 & 0.000 & 0.48 & 0.48 \\
\hline FOR & 24.402 & 21.568 & 21.673 & 18.912 & $3.24 * * *$ & $3.21 * * *$ \\
\hline$L A R G E$ & 35.594 & 35.130 & 37.746 & 35.800 & $-2.43 * *$ & $-2.03 * *$ \\
\hline POSUE & 0.659 & 1.000 & 0.601 & 1.000 & $2.22 * *$ & $2.21 * *$ \\
\hline$L O S S_{t-1}$ & 0.029 & 0.000 & 0.047 & 0.000 & $-1.89^{*}$ & $-2.01 * *$ \\
\hline SIZE & 27.540 & 27.582 & 27.604 & 27.667 & 0.55 & 0.38 \\
\hline GROWTH & 0.126 & 0.097 & 0.110 & 0.092 & 1.04 & 1.35 \\
\hline$R O A$ & 0.086 & 0.076 & 0.071 & 0.065 & $3.74 * * *$ & $4.03 * * *$ \\
\hline$N$ & 5.076 & 3.000 & 4.956 & 3.000 & 1.05 & 0.68 \\
\hline
\end{tabular}

$B E A T=1$ if actual $\mathrm{EPS}_{\mathrm{t}} \geq$ mean of analyst EPS forecast in 1 month before earnings announcement, otherwise $0 ; P O S D A=1$ if $\mathrm{DA} \geq 0$, otherwise 0 (DA is residual value of performance matched model); $D O W N=1$ if $\mathrm{UEF}<0$, otherwise $0(\mathrm{UEF}=$ mean of analyst EPS forecast-expected analyst EPS forecast defined as equation (3)); FOR=foreign ownership; $L A R G E=$ large shareholders' ownership; POSUE=1 if net income $\geq$ net income $_{\mathrm{t}-1}$, otherwise $0 ; L O S S_{t-1}=1$ if net income $\mathrm{t}_{-1}<0$, otherwise 0 ; SIZE=log of market value of equity; GROWTH=chages of total asset; ROA=ratio of net income $_{\mathrm{t}}$ over total asset; $N=$ number of individual analysts who issue earnings forecast for each firm.

Table 3 presents the correlations between each variable. BEAT demonstrates a significant positive correlation with POSDA $(0.131, \mathrm{p}<0.001)$. There is a positive association between BEAT and DOWN, with a correlation coefficient of $0.015(\mathrm{p}=0.632)$. In the univariate analysis, we cannot assert whether firms who meet or beat market expectations increase the downward forecast guidance. However, managers of BEAT firms have strong incentives to increase earnings management.

Table 3: Correlation Analysis

\begin{tabular}{|c|c|c|c|c|c|c|c|c|c|c|c|}
\hline & $(1)$ & (2) & (3) & (4) & (5) & (6) & (7) & (8) & (9) & $(\mathbf{1 0})$ & (11) \\
\hline \multirow{2}{*}{ (1)BEAT } & 1 & 0.131 & 0.015 & 0.096 & -0.072 & 0.066 & -0.060 & 0.016 & 0.032 & 0.111 & 0.030 \\
\hline & & $<.0001$ & 0.632 & 0.001 & 0.015 & 0.027 & 0.044 & 0.585 & 0.291 & 0.000 & 0.309 \\
\hline \multirow{2}{*}{ (2)POSDA } & & 1 & -0.110 & 0.052 & 0.074 & 0.063 & -0.113 & 0.022 & 0.159 & 0.255 & 0.033 \\
\hline & & & 0.001 & 0.000 & $<.0001$ & $<.0001$ & $<.0001$ & 0.113 & $<.0001$ & $<.0001$ & 0.153 \\
\hline \multirow{2}{*}{ (3)DOWN } & & & 1 & -0.074 & 0.026 & -0.194 & -0.067 & -0.131 & -0.120 & -0.150 & -0.112 \\
\hline & & & & 0.017 & 0.399 & $<.0001$ & 0.032 & $<.0001$ & 0.000 & $<.0001$ & 0.000 \\
\hline \multirow{2}{*}{ (4)FOR } & & & & 1 & -0.127 & 0.023 & -0.130 & 0.591 & 0.039 & 0.190 & 0.403 \\
\hline & & & & & $<.0001$ & 0.077 & $<.0001$ & $<.0001$ & 0.003 & $<.0001$ & $<.0001$ \\
\hline \multirow{2}{*}{ (5)LARGE } & & & & & 1 & -0.017 & -0.096 & -0.058 & 0.076 & 0.092 & -0.218 \\
\hline & & & & & & 0.214 & $<.0001$ & $<.0001$ & $<.0001$ & $<.0001$ & $<.0001$ \\
\hline \multirow{2}{*}{ (6)POSUE } & & & & & & 1 & 0.138 & 0.083 & 0.157 & 0.326 & 0.101 \\
\hline & & & & & & & $<.0001$ & $<.0001$ & $<.0001$ & $<.0001$ & $<.0001$ \\
\hline \multirow{2}{*}{ (7) $\operatorname{LOSS}_{t-1}$} & & & & & & & 1 & -0.215 & -0.079 & -0.430 & -0.045 \\
\hline & & & & & & & & $<.0001$ & $<.0001$ & $<.0001$ & 0.048 \\
\hline \multirow{2}{*}{ (8)SIZE } & & & & & & & & 1 & 0.189 & 0.293 & 0.560 \\
\hline & & & & & & & & & $<.0001$ & $<.0001$ & $<.0001$ \\
\hline
\end{tabular}


Table 3 cont.

\begin{tabular}{l|ccc}
\hline (9)GROWTH & $\mathbf{1}$ & $\mathbf{0 . 2 5 1}$ & $\mathbf{0 . 0 7 8}$ \\
& & $<.0001$ & $\mathbf{0 . 0 0 1}$ \\
$(10)$ ROA & & 0.178 \\
$(11) N$ & $<.0001$ \\
\hline
\end{tabular}

$B E A T=1$ if actual $\mathrm{EPS}_{\mathrm{t}} \geq$ mean of analyst EPS forecast in 1 month before earnings announcement, otherwise $0 ; P O S D A=1$ if $\mathrm{DA} \geq 0$, otherwise 0 (DA is residual value of performance matched model); $D O W N=1$ if $\mathrm{UEF}<0$, otherwise $0(\mathrm{UEF}=$ mean of analyst EPS forecast-expected analyst EPS forecast defined as equation (3)); FOR=foreign ownership; $L A R G E=$ large shareholders' ownership; POSUE=1 if net income $\geq$ net income $\mathrm{t}_{\mathrm{t}-1}$, otherwise 0; $\operatorname{LOSS}_{t-1}=1$ if net income $\mathrm{t}_{-1}<0$, otherwise 0; SIZE=log of market value of equity; GROWTH=chages of total asset; ROA=ratio of net income $_{\mathrm{t}}$ over total asset $N=$ number of individual analysts who issue earnings forecast for each firm.

\subsection{Tests of Incentives to Beat Market Expectations}

Table 4 reports the logit regression results for Equation (5). Model 1 presents the results using only FOR in the logit regression, whereas Model 2 reports the results using $L A R G E$ in place of FOR. Model 3 includes both FOR and LARGE in the logit regression. In Model 1 and Model 3, the coefficient on FOR is positive and significant, suggesting that firms with higher foreign ownership are more likely to meet or exceed market expectations. Consistent with H1a, we find that managers with higher foreign ownership have strong incentives to avoid negative earnings surprises. Managers with higher foreign ownership are more likely concerned with negative earnings surprises because such surprises will lead to significantly lower stock prices and further, adversely affect foreign owners' near-term portfolio performance. The significant negative coefficient on LARGE in Model 1 and Model 3 supports H1b-firms with larger shareholder ownership are less likely to meet or beat market expectations. Due to the notion that large shareholders are not sensitive to the drop in stock prices, managers with larger shareholder ownership perceive lower costs compared to missing analysts' forecasts.

Table 4: Meeting or Beating Analysts' Earnings Forecasts by Ownership

\begin{tabular}{|c|c|c|c|c|c|c|c|}
\hline \multirow[t]{2}{*}{ Variables } & \multirow[t]{2}{*}{ Predicted sign } & \multicolumn{2}{|c|}{ Model 1} & \multicolumn{2}{|c|}{ Model 2} & \multicolumn{2}{|c|}{ Model 3} \\
\hline & & Estimate & $\begin{array}{l}\text { Wald chi- } \\
\text { square }\end{array}$ & Estimate & $\begin{array}{c}\text { Wald chi- } \\
\text { square }\end{array}$ & Estimate & $\begin{array}{c}\text { Wald chi- } \\
\text { square }\end{array}$ \\
\hline Intercept & & 1.277 & 0.05 & 0.051 & 0.00 & 1.071 & 0.66 \\
\hline $\begin{array}{l}\text { FOR } \\
L A R G E\end{array}$ & $\begin{array}{l}+ \\
-\end{array}$ & 0.004 & $5.77 * *$ & -0.010 & $7.33 * * *$ & $\begin{array}{c}0.008 \\
-0.009\end{array}$ & $\begin{array}{l}4.03 * * \\
5.58 * *\end{array}$ \\
\hline $\begin{array}{l}\text { POSUE } \\
\text { LOSS }_{t-1} \\
\text { SIZE } \\
\text { GROWTH }\end{array}$ & $\begin{array}{l}+ \\
- \\
+ \\
+\end{array}$ & $\begin{array}{l}0.127 \\
0.315 \\
0.046 \\
0.355 \\
\end{array}$ & $\begin{array}{c}4.69 * * \\
1.13 \\
0.60 \\
2.69 \\
\end{array}$ & $\begin{array}{c}0.269 \\
-0.432 \\
-0.005 \\
0.656 \\
\end{array}$ & $\begin{array}{c}4.45 * * \\
1.88 \\
0.02 \\
3.34 * \\
\end{array}$ & $\begin{array}{c}0.266 \\
-0.371 \\
-0.050 \\
0.653 \\
\end{array}$ & $\begin{array}{c}4.34 * * \\
1.38 \\
1.18 \\
3.32 *\end{array}$ \\
\hline$Y R$ & & \multicolumn{2}{|c|}{ included } & \multicolumn{2}{|c|}{ included } & \multicolumn{2}{|c|}{ included } \\
\hline \multicolumn{2}{|c|}{$\begin{array}{c}\mathrm{N} \\
\text { Log Likelihood } \\
\end{array}$} & \multicolumn{2}{|c|}{$\begin{array}{c}1,255 \\
54.14 * * *\end{array}$} & \multicolumn{2}{|c|}{$\begin{array}{c}1,255 \\
55.68 * * * \\
\end{array}$} & \multicolumn{2}{|c|}{$\begin{array}{c}1,255 \\
59.74 * * * \\
\end{array}$} \\
\hline
\end{tabular}

$B E A T=1$ if actual $E S_{\mathrm{t}} \geq$ mean of analyst EPS forecast in 1 month before earnings announcement, otherwise 0; FOR=foreign ownership; $L A R G E=$ large shareholders' ownership; POSUE $=1$ if net income $\geq$ net income $\mathrm{t}_{\mathrm{t}-1}$, otherwise $0 ;$ LOSS $_{t-1}=1$ if net income $\mathrm{t}_{-1}<0$, otherwise 0 ; SIZE $=\log$ of market value of equity; GROWTH=chages of total asset; YR=dummy variable if each year. Notes: *, **, *** represent the significances at the 10,5 , and 1 percent levels, respectively.

\subsection{Tests of Methods to Beat Market Expectations}

Table 5 presents the regression results for Equation (6). Consistent with prior researches (Brown, 2001; Matsumoto, 2002; Brown \& Caylor, 2005), which find that firms meeting or beating analyst estimates generally use accrual-based earnings management, the findings indicate a significantly positive association between $B E A T$ and $P O S D A$. We find a significantly negative sign for $\beta_{2}(B E A T \times F O R)(-0.016, \mathrm{p}=0.040)$, suggesting that firms who meet or beat market expectations decrease the use of income-increasing accruals with higher foreign ownership. The negative sign of $\beta_{2}(B E A T \times L A R G E)(-0.013, \mathrm{p}=0.066)$ suggests that firms who meet or beat market expectations also decrease in their upward earnings management as larger shareholder ownership increases. 
Table 5: Earnings Management to Meet or Beat Analysts' Earnings Forecasts by Ownership

\begin{tabular}{|c|c|c|c|c|c|}
\hline \multicolumn{6}{|c|}{$P O S D A_{t}=\alpha+\beta_{1} B E A T_{t}+\beta_{2} B E A T_{t} \times F O R_{t}\left(L A R G E_{t}\right)+\beta_{3} F O R_{t}+\beta_{4} L A R G E_{t}+\beta_{5} S I Z E_{t}+\beta_{6} G R O W T H_{t}+\sum_{n=7}^{15} \beta_{n} Y R+\varepsilon$} \\
\hline Variables & Predicted sign & Estimate & Wald chi-square & Estimate & Wald chi-square \\
\hline Intercept & & 4.754 & $11.42 * * *$ & 4.242 & $12.23 * * *$ \\
\hline$B E A T$ & + & 0.661 & $9.74 * * *$ & 0.576 & $4.02 * *$ \\
\hline$B E A T \times F O R$ & $+1-$ & -0.016 & $4.24 * *$ & & \\
\hline$B E A T \times L A R G E$ & - & & & -0.013 & $3.37 *$ \\
\hline FOR & + & 0.008 & 1.68 & -0.005 & 2.13 \\
\hline$L A R G E$ & + & 0.001 & 0.22 & 0.002 & 0.22 \\
\hline SIZE & + & -0.190 & $15.06 * * *$ & -0.151 & $12.70 * * *$ \\
\hline GROWTH & + & 0.334 & 0.89 & 0.340 & 1.35 \\
\hline$Y R$ & & \multicolumn{2}{|c|}{ included } & \multicolumn{2}{|c|}{ included } \\
\hline $\log$ & lihood & \multicolumn{2}{|c|}{$\begin{array}{c}1,255 \\
58.63 * * *\end{array}$} & \multicolumn{2}{|c|}{$\begin{array}{c}1,255 \\
41.37 * * *\end{array}$} \\
\hline
\end{tabular}

Table 6 reports the results on the relation between beating market expectations and expectations management as well as the changes in its relation with the ownership structure in Korea. As expected, we find a positive sign for the coefficient on BEAT $(0.327, \mathrm{p}=0.042)$, representing that firms meeting or beating analysts' forecasts utilize downward forecast guidance. Our results are consistent with Brown and Higgins (2005), which show that, in the case of Korea, the probability that the current earnings meet or beat analyst estimates and $D O W N=$ 1 for periods from 1991 to 2000 are almost 14.66. Moreover, our findings support the result of Matsumoto (2002), which show managers as to who beat analysts' estimates using both earnings management and expectations management.

Table 6: Expectations Management to Meet or Beat Analysts' Earnings Forecasts by Ownership

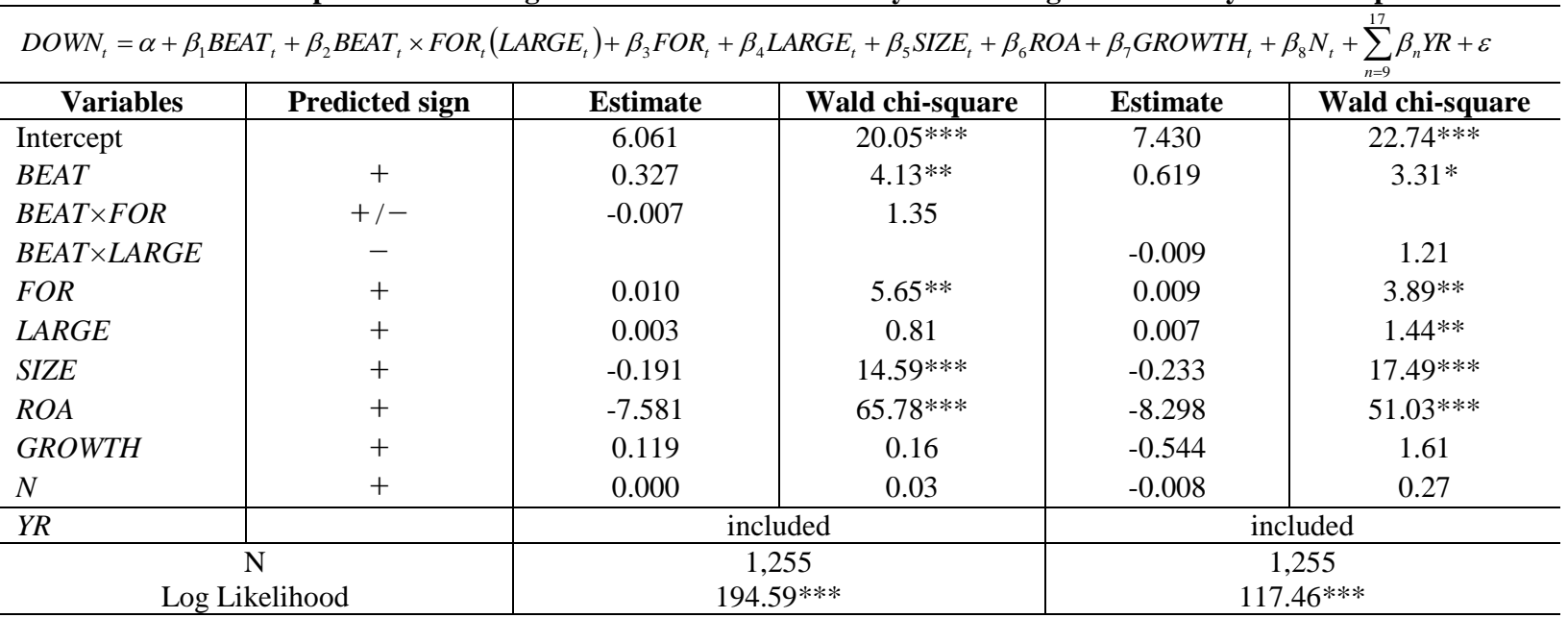

$P O S D A=1$ if $\mathrm{DA} \geq 0$, otherwise 0(DA is residual value of performance matched model; $D O W N=1$ if $\mathrm{UEF}<0$, otherwise 0 (UEF $=$ mean of analyst EPS forecast-expected analyst EPS forecast defined as equation (3));BEAT=1 if actual $\mathrm{EPS}_{\mathrm{t}} \geq$ mean of analyst EPS forecast in 1 month before earnings announcement, otherwise 0; FOR=foreign ownership; $L A R G E=$ large shareholders' ownership; POSUE=1 if net income $\geq$ net income $_{t-1}$,

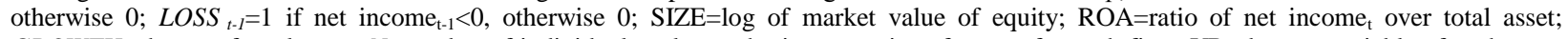
GROWTH=chages of total asset; $N=$ number of individual analysts who issue earnings forecast for each firm; YR=dummy variable of each year. Notes: *,**,** represent the significances at the 10,5 , and 1 percent levels, respectively.

\section{ADDITIONAL ANALYSIS}

Our results find that firms who try to meet or beat analysts' earnings forecasts use both earnings management and expectations management, consistent with prior researches (Matsumoto, 2002; Bartov et al., 2002; Brown \& Higgins, 2001). However, some may be concerned with whether the proxies that measure meeting or beating market expectations are capturing earnings and/or expectations management, or whether these trends result from some other phenomenon. To provide construct validity for our proxies, we conduct an additional analysis using 
"suspect firms." Firms exactly meeting or slightly beating the targets due to a greater likelihood of managerial intervention in earnings and/or expectations management are expected to be observed here. We define this small beater (SMBEAT) as a dummy variable, which is set to one if the firm's actual earnings per share exceed the analysts' forecasts by 100 won per share or less. ${ }^{4}$ To assess whether small beaters increase earnings and/or expectations management with corporate ownership in Korea, we employ the following regressions.

$\operatorname{POSDA}_{t}=\alpha+\beta_{1} S M B E A T_{t}+\beta_{2} S_{M B E A T_{t}} \times$ FOR $_{t}\left(L A R G E_{t}\right)+\beta_{3} F O R_{t}+\beta_{4} L A R G E_{t}+\beta_{5} \operatorname{SIZE}_{t}+\beta_{6} G R O W T H_{t}+\sum_{n=7}^{15} \beta_{n} Y R+\varepsilon$

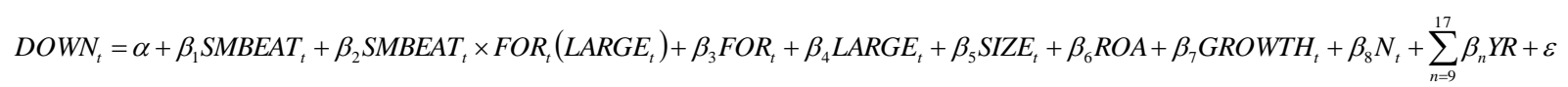

where $S M B E A T=1$ if $0 \leq\left(\right.$ PPS $_{\mathrm{t}}$-mean analyst forecast $) \leq 100$ otherwise 0

In Panel A of Table 7, we find significant positive associations between SMBEAT and POSDA $(0.411, \mathrm{p}=$ 0.05). These findings suggest that managers of SMBEAT firms seek to avoid negative earnings surprises by increasing the accruals. However, the negative sign of $S M B E A T \times F O R$ explains that the positive association between SMBEAT and POSDA decreases as foreign ownership increases. These findings suggest that SMBEAT firms are unlikely to use earnings management if foreign ownership is high. On the other hand, no such effects are found regarding large shareholder ownership. Panel B of Table 7 presents the estimation result for expectations management of SMBEAT firms with ownership structure. Our results present that the coefficient of SMBEAT is significantly positive, representing that firms who exactly meet or slightly beat expectations use downward forecast guidance. Therefore, these findings expand the result of Brown and Higgins (2005) in that firms that meet or slightly beat expectations increases the likelihood of using downward expectations management in Korea. However, the positive associations between $S M B E A T$ and $D O W N$ do not change with ownership structures, such as foreign ownership and large shareholder ownership.

Table 7: Earnings Management and Expectations Management for Firms to Meet or Slightly Beat Market Expectations Panel A: Earnings Management

POSDA $_{t}=\alpha+\beta_{1} S_{M B E A T_{t}}+\beta_{2} \operatorname{SMBEAT}_{t} \times$ FOR $_{t}\left(L A R G E_{t}\right)+\beta_{3} F O R_{t}+\beta_{4} L A R G E_{t}+\beta_{5} S I Z E_{t}+\beta_{6} G R O W T H_{t}+\sum_{n=7}^{15} \beta_{n} Y R+\varepsilon$

\begin{tabular}{|c|c|c|c|c|c|}
\hline Variables & Predicted sign & Estimate & Wald chi-square & Estimate & Wald chi-square \\
\hline Intercept & & 4.740 & $21.53 * * *$ & 6.191 & $33.72 * * *$ \\
\hline SMBEAT & + & 0.411 & $3.83 *$ & 0.189 & 0.36 \\
\hline$S M B E A T \times F O R$ & $+1-$ & -0.012 & $2.82 *$ & & \\
\hline$S M B E A T \times L A R G E$ & - & & & 0.002 & 0.09 \\
\hline FOR & + & 0.010 & $3.71 *$ & 0.017 & $17.85^{* * *}$ \\
\hline$L A R G E$ & + & 0.002 & 0.34 & 0.000 & 0.01 \\
\hline SIZE & + & -0.231 & $25.80 * * *$ & -0.323 & $46.12 * * *$ \\
\hline GROWTH & + & 0.406 & 1.33 & 1.482 & $15.40 * * *$ \\
\hline$Y R$ & & \multicolumn{2}{|c|}{ included } & \multicolumn{2}{|c|}{ included } \\
\hline \multicolumn{2}{|c|}{$\begin{array}{c}\mathrm{N} \\
\text { Log Likelihood }\end{array}$} & \multicolumn{2}{|c|}{$\begin{array}{c}1,255 \\
51.33 * * *\end{array}$} & \multicolumn{2}{|c|}{$\begin{array}{c}1,255 \\
41.37 * * *\end{array}$} \\
\hline
\end{tabular}

Panel B: Expectations Management

$D O W N_{t}=\alpha+\beta_{1} S_{M B E A T_{t}}+\beta_{2} \operatorname{SMBEAT}_{t} \times$ FOR $_{t}\left(L A R G E_{t}\right)+\beta_{3} F O R_{t}+\beta_{4} L A R G E_{t}+\beta_{5} S I Z E_{t}+\beta_{6} R O A+\beta_{7} G R O W T H_{t}+\beta_{8} N_{t}+\sum_{n=9}^{17} \beta_{n} Y R+\varepsilon$

\begin{tabular}{l|c|c|c|c|c}
\hline \multicolumn{1}{c|}{ Variables } & Predicted sign & Estimate & Wald chi-square & Estimate & Wald chi-square \\
\hline Intercept & & 7.161 & $21.79 * * *$ & 7.151 & $21.74 * * *$ \\
SMBEAT & + & 0.561 & $6.42 * *$ & 0.682 & $4.38^{* *}$ \\
SMBEAT $\times F O R$ & $+/-$ & -0.006 & 0.63 & & \\
SMBEAT $\times L A R G E$ & - & & & -0.007 & 0.78 \\
FOR & + & 0.013 & $5.33 * *$ & 0.010 & $4.87 * *$ \\
\hline
\end{tabular}

${ }^{4}$ Won is Korean currency. 
Table 7 cont.

\begin{tabular}{|c|c|c|c|c|c|}
\hline LARGE & + & 0.000 & 0.03 & 0.004 & 0.55 \\
\hline SIZE & + & -0.241 & $19.13 * * *$ & -0.242 & $19.37 * * *$ \\
\hline$R O A$ & + & -7.807 & $50.08 * * *$ & -7.868 & $50.92 * * *$ \\
\hline GROWTH & + & -0.718 & $2.92 *$ & -0.697 & $2.76^{*}$ \\
\hline$N$ & + & -0.011 & 0.49 & -0.010 & 0.44 \\
\hline$Y R$ & & \multicolumn{2}{|c|}{ included } & \multicolumn{2}{|c|}{ included } \\
\hline \multicolumn{2}{|c|}{$\begin{array}{c}\mathrm{N} \\
\text { Log Likelihood }\end{array}$} & \multicolumn{2}{|c|}{1,255} & \multicolumn{2}{|c|}{1,255} \\
\hline
\end{tabular}

SMBEAT $=1$ if $0 \leq\left(\mathrm{EPS}_{\mathrm{t}}\right.$-mean analyst forecast) $\leq \$ 100$ otherwise $0 ; P O S D A=1$ if $\mathrm{DA} \geq 0$, otherwise 0 (DA is residual value of performance matched model); $D O W N=1$ if $\mathrm{UEF}<0$, otherwise $0(\mathrm{UEF}=$ mean of analyst EPS forecast-expected analyst EPS forecast defined as equation (3)); $F O R=$ foreign ownership; $L A R G E=$ large shareholders' ownership; POSUE $=1$ if net income $\geq$ net income $_{t-1}$, otherwise $0 ; L O S S_{t-l}=1$ if net income ${ }_{1}<0$, otherwise 0; SIZE=log of market value of equity; GROWTH=chages of total asset; ROA=ratio of net income ${ }_{\mathrm{t}}$ over total asset; $N=$ number of individual analysts who issue earnings forecast for each firm. Notes: *, **, *** represent the significances at the 10,5 , and 1 percent levels, respectively.

However, we cannot find significant results for each coefficient of both $B E A T \times F O R$ and $B E A T \times L A R G E$. We expect firms who meet or beat analysts' estimates rely more on downward forecasts rather than on earnings management with higher foreign ownership because foreign investors limit managers' ability to acquire private control benefits. However, our findings indicate that the changes in ownership structure in Korea do not affect managerial behavior to meet or beat market expectations.

\section{CONCLUSION}

Our studies investigate whether managers change their behavior related to meeting or beating expectations, depending on the ownership structure in Korea. We also examine whether the ownership structure changes meeting or beating market expectations by means of earnings management and/or expectations management.

First, we discover that firms with higher foreign ownership are more likely to meet or beat market expectations while firms with larger shareholder ownership are less likely to meet or beat analysts' earnings forecasts. Our results portray that managers perceive greater costs to missing analysts' earnings forecasts since foreign owners emphasize current-term profits. Our findings suggest that large shareholders' ownership has an important influence on internal monitoring efforts on manager's earnings and/or expectations management. Furthermore, our results show managers with large shareholders' ownership tend to purse long-term firm value rather than near-term profits since large shareholders ownership is beneficial once it better aligns managers' interests with those of shareholders.

Second, firms that meet or beat market expectations rely less on income-increasing discretionary accruals with higher foreign ownership and larger shareholder ownership. These findings suggest that foreign ownership plays an important outside monitoring role in Korea such that managers decrease earnings management as foreign ownership increases. In addition, media attention focuses primarily on managers' use of accounting discretion, resulting in the decrease of managers' opportunistic behavior for their own interests. As for firms with higher foreign ownership, we expect, given the relative difficulty of managing earnings upward, managers are relatively more likely to use forecast guidance because the regulation of forecast guidance is far less rigorous than that of earnings management. However, we cannot find any significant results for expectations management as foreign ownership increases.

Our study represents an initial attempt to examine the relationships between ownership structure in Korea and managers' behavior in order to meet or beat market expectations. Although the earnings management literature is relatively well developed, no previous study has examined the relationship between ownership structure in Korea and managers' behavior in order to avoid negative earnings surprises. The results provide additional evidence for the convergence-of-interest hypothesis that as the controlling shareholder's ownership level increases, the interest of the controlling shareholder decreases managers' opportunistic behavior to manage earnings. The results add to the growing body of literature that finds a link between corporate governance mechanisms and various facets of earnings management as well as expectations management. 


\section{ACKNOWLEDGEMENT}

This work was supported by research fund of Chungnam National University.

\section{AUTHOR INFORMATION}

Hyewon Paik is an assistant professor of School of Business, Chungnam National University, 99 Daehak-ro, Yuseong-gu, Daejeon, 305-764, Korea. E-mail: hwpaik@cnu.ac.kr

Yunsung Koh is an associate professor of Accounting at School of Business, Hankuk University of Foreign Studies, 107 Imun-ro, Dongdaemun-gu, Seoul, 130-791, Korea. E-mail: max0907@ hufs.ac.kr (Corresponding author)

\section{REFERENCES}

1. Ahn, Y. Y., Shin, H. H., \& Chang, J. H. (2005). The relationship between the foreign investor and information asymmetry. Korean Accounting Review, 30(4), 109-131.

2. Bartov, E., Givoly, D., \& Hayn, C. (2002). The rewards to meeting or beating earnings expectations. Journal of Accounting and Economics, 33(2), 173-204.

3. Brous, P. A., \& Kini, O. (1993). A reexamination of analysts' earnings forecasts for takeover targets. Journal of Financial Economic, 33, 201-225.

4. Brown, L. D. (1997). Analyst forecasting errors: Additional evidence. Financial Analysts' Journal, 53(6), 81-88.

5. Brown, L. D. (2001). A temporal analysis of earnings surprises: Profits versus losses. Journal of Accounting Research, 39(2), 221-241.

6. Brown, L. D., \& Caylor, M. C. (2005). A temporal analysis of quarterly earnings thresholds: Propensities and valuation consequences. The Accounting Review, 80(2), 423-440.

7. Brown, L. D., Griffin, P., Hagerman, R., \& Zmijewski, M. (1987). An evaluation of alternative proxies for the market's assessment of unexpected earnings. Journal of Accounting and Economics, 9, 159-194.

8. Brown, L. D., \& Higgins, H. N. (2001). Managing earnings surprises in the US versus 12 other countries. Journal of Accounting and Public Policy, 20, 373-398.

9. Brown, L. D., \& Higgins, H. N. (2005). Managers' forecast guidance of analysts: International evidence. Journal of Accounting and Public Policy, 24, 280-299.

10. Burgstahler, D., \& Eames, M. (2006). Management of earnings and analysts' forecasts to achieve zero and small earnings surprises. Journal of Business Finance and Accounting, 33(5-6), 633-652.

11. Collins, D. W., \& Kothari, S. P. (1989). An analysis of intertemporal and cross-sectional determinants of earnings response coefficients. Journal of Accounting and Economics, 11, 143-181.

12. Das, S., Levine, C. B., \& Sivaramakrishnan, K. (1998). Earnings predictability and bias in analysts' earnings forecasts. The Accounting Review, 73(2), 277-294.

13. Degeorge, F., Patel, J., \& Zeckhauser, R. (1999). Earnings management to exceed thresholds. Journal of Business, 72(1), 1-33.

14. Fan, P. H., \& Wong, T. J. (2002). Corporate ownership structure and the informativeness of accounting earnings in East Asia. Journal of Accounting and Economics, 33(3), 401-25.

15. Fields, T. D., Lys, T. Z., \& Vincent, L. (2001). Empirical research on accounting choice. Journal of Accounting and Economics, 31(1), 255-307.

16. Gomes, A. (2000). Going public without governance: managerial reputation effects. Journal of Finance, 55, 615-646.

17. Graham, J., Harvey, C., \& Rajgopal, S. (2005). The economic implications of corporate financial reporting. Journal of Accounting and Economics, 40, 3-73.

18. Healy, P., \& Palepu, K. (2001). Information asymmetry, corporate disclosure, and capital markets: A review of the empirical disclosure literature. Journal of Accounting and Economics, 31, 405-440.

19. Ip, G. (1997). Traders laugh off the official estimate on earnings, act on whispered numbers. Wall Street Journal (January 16), C1.

20. Kaplan, S. N. (1994). Top executives, turnover, and firm performance in Germany. Journal of Law Economics and Organization, 10(1), 142-159. 
21. Koh, K., Matsumoto, D., \& Rajgopal, S. (2008). Meeting or beating analyst expectations in the postscandal world: Changes in stock market rewards and managerial actions. Contemporary Accounting Research, 25(4), 1067-1098.

22. Kothari, S. P., Leone, A. J., \& Wasley, C. E. (2005). Performance matched discretionary accrual measures. Journal of Accounting and Economics, 39, 163-197.

23. La Porta, R., Lopez-De-Silanes, F., \& Shleifer, A. (1999). Corporate ownership around the world. The Journal of Finance, 54(2), 471-518.

24. Lee, J. H., \& Sohn, S. K. (2005). An empirical analysis of the relationship between corporate governance and corporate disclosure practices in Korea. Korean Accounting Review, 30(3), 33-69.

25. Matsumoto, D. A. (2002). Management's incentives to avoid negative earnings surprises. The Accounting Review, 77, 483-514.

26. Park, J. I. (2003). Corporate governance and earnings management: View from the largest shareholder's holding. Korea Accounting Review, 28(2), 135-172.

27. Park, J. I., \& Jeon, K. A. (2010). Earnings managements to avoid negative earnings surprises. Accounting Information Review, 28(1), 135-174.

28. Park, J. I., Jeon, K. A., Choi, J. H., \& Park, C. W. (2009). The role of large auditors in restricting the earnings management by largest shareholders' and foreign investors' ownership. Accounting Information Review, 27(1), 201-229.

29. Payne, J. L., \& Robb, S. W. G. (2000). Earnings management: The effect of ex ante earnings expectations. Journal of Accounting, Auditing, and Finance, 15(4), 371-392.

30. Richardson, S., Teoh, S. H., \& Wysocki, P. (1999). Tracking analysts' forecasts over the annual earnings horizon: Are analysts' forecasts optimistic or pessimistic? (Working paper). University of Michigan, Ann Arbor, MI.

31. Shleifer, A., \& Vishny, R. (1986). Large shareholders and corporate control. Journal of Political Economy, 94, 461-88.

32. Skinner, D. J., \& Sloan, R. G. (2002). Earnings surprises, growth expectations and stock returns or don't let a torpedo stock sink your portfolio. Review of Accounting Studies, 7, 289-312.

33. Shin, H. H., \& Chang, J. H. (2005). An analysis of the determinants of CEO turnover: Firm performance, professional CEO, and business group. Korean Management Review, 34(1), 289-311.

34. Shin, H. H., Lee, S. C., \& Chang, J. H. (2004). Outside monitors and firm value. The Korean Journal of Finance, 17(1), 41-72.

35. Teoh, S. H., \& Wong, T. J. (1993). Perceived auditor quality and the earnings response coefficients. The Accounting Review, 68, 346-67. 